\title{
Bring Back the Politics: The PSPP Ruling in Its Institutional Context
}

\author{
Teresa Violante
}

(Received 20 July 2020; accepted 20 July 2020)

\begin{abstract}
In this paper, I argue that the conflict between the German Federal Constitutional Court and the Court of Justice of the European Union is the story of a clash foretold, if one takes seriously constitutional courts as institutions designed to be "dogs that bite." The German Court consistently developed a doctrinal tool to guide its role as guardian of the national constitutional order and the democratic principle, and enforced it when the constitutional control of monetary policy measures so required. I analyze the PSPP ruling, focusing on where the Court concluded that the lack of a satisfactory statement of reasons by the European Central Bank prevented it from reviewing the proportionality of the program. I argue that the Court, after conducting a substantive assessment, applied a weak remedy, thereby deferring the last word on the constitutionality of the PSPP to the political branches. In doing so, the Court opens space for the political assessment of a controversial monetary policy, enhancing the politicization of the Economic and Monetary Union, and provides a doctrinal toolbox for national constitutional courts that face competence creep of EU law in their jurisdictions. I conclude that, ultimately, the main merit of constitutional courts' interventions in the EU integration is that they are in a privileged position to allow for the politicization of technocratic processes.
\end{abstract}

Keywords: constitutional adjudication; Court of Justice of the European Union; Federal Constitutional Court; proportionality; deference

\section{A. The Story of a Clash Foretold}

In the novel "Chronicle of a Death Foretold" by the Colombian writer Gabriel García Márquez, the reader is introduced from the beginning to the foretold death of Santiago Nasar at the hands of the Vicario twins, infuriated by the suspicion that he was to blame for their sister's dishonor. As the story evolves, the reader cannot help but feel the anguish grow. She already knows the end to the story, Santiago will die, but at the same time, she wishes that his death could be prevented, that fate could be unwritten and the catastrophe avoided. Several remedies to prevent Santiago's death are explored in the plot. However, they are all doomed to failure, either for lack of will, wickedness, neglect, or sheer misfortune. The end is laid down from the beginning: It is a chronicle of a foretold death, as the title indicates.

If we survey the literature on the relationship between Karlsruhe and Luxembourg preceding the recent $P S P P$ ruling, we may get this same feeling of inevitability and simultaneous eagerness to avoid the disaster: A potential clash between the German Federal Constitutional Court (hereinafter FCC)

\footnotetext{
${ }^{\star}$ Research Fellow, Friedrich-Alexander Universität (FAU) Erlangen-Nürnberg. The research leading to this paper has been funded by the German Research Foundation/Deutsche Forschungsgemeinschat (DFG) in the framework of the EmmyNoether Project on "Transnational Solidarity Conflicts" at FAU Erlangen-Nürnberg. I would like to thank Matthias Goldmann for his insightful comments and suggestions.
} 
and the Court of Justice of the European Union (hereinafter CJEU) has both frightened and fascinated scholars to the point where we can say that this is the story of a clash foretold.

In this paper, I argue that the conflict between the German Federal Constitutional Court and the Court of Justice of the European Union is the story of a clash foretold if one takes seriously constitutional courts as institutions designed to be "dogs that bite." The German Court consistently developed a doctrinal tool to guide its role as guardian of the national constitutional order and the democratic principle, and enforced it when the constitutional control of monetary policy measures so required. Whereas the Court of Justice accepted the judicial review of the European Central Bank's acts under a procedural standard, the German Court's doctrinal tool includes the substantial review of monetary policies with significant fiscal and economic effects. This distinction eventually proved fatal for the cooperative relationship between the two courts (B). I analyze the PSPP ruling insofar as the Court concluded that the lack of a satisfactory statement of reasons by the European Central Bank prevented it from reviewing the proportionality of the program. The German Court rejected the Court of Justice's authority for failure to hold the Central Bank into account after conducting a substantive assessment of the PSPP. Furthermore, I argue that the German Court applied a weak remedy, thereby deferring the last word on the constitutionality of the PSPP to the political branches. In doing so, the Court opens space for the political assessment of a controversial monetary policy, enhancing the politicization of the Economic and Monetary Union, and provides a doctrinal toolbox for national constitutional courts that face competence creep of EU law in their jurisdictions (D). I conclude that, ultimately, the main merit of constitutional courts' interventions in the EU integration is that they are in a privileged position to allow for the politicization of technocratic processes $(\mathrm{E})$.

\section{B. Preparing to Bite}

From a Luxembourg-centered perspective, the FCC has long been qualified as a court that bites. The literature on this topic is very suggestive of this canine trend. ${ }^{1}$ What may be more puzzling is the surprise with which commentators and observers receive every new bite. Indeed, biting has been qualified as an essential feature of the constitutional jurisdiction. In his account of judicial review, Martin Shapiro developed the concept of constitutional courts as "junkyard dogs."2 When constitution-makers decide on questions related to the division of powers and oversight, they have a limited set of institutional choices at their disposal. Once the decision is made, people will need to conform to the institutional consequences of those fundamental choices, as it is expected that institutions will act in accordance with their (institutional) nature. Against this backdrop, constitutional courts are institutions that bite:

The "junk yard dog" is a fierce dog kept confined during business hours and set loose to roam the junk yard all night attacking any and all interlopers. As to the owner of the junk yard who, for some reason, enters at midnight and comes to canine grief, there is a saying: "If you buy a junk yard $\operatorname{dog} \ldots "(\ldots)$

\footnotetext{
${ }^{1}$ See, e.g., Niels Petersen, Karlsruhe not only Barks, But Finally Bites - Some Remarks on the OMT Decision of the German Constitutional Court, 15 German L.J. 321 (2014); Christoph U. Schmid, All Bark and No Bite: Notes on the Federal Constitutional Court's 'Banana Decision', 7 Eur. L.J. 95 (2001); Peter Lindseth, Barking vs. Biting: Understanding the German Constitutional Court's OMT reference... and its implications for EU Reform, EUTOPIA LAW (Feb. 10, 2014), http://eutopialaw.com/2014/02/10/barking-vs-biting-understanding-the-german-constitutional-courts-omt-referenceand-its-implications-for-eu-reform/. In 2009, after the Lisbon ruling, Joseph Weiler said that the German Constitutional Court "has a well-earned reputation of the Dog that Barks but does not Bite". See Joseph Weiler, Editorial. The 'Lisbon Urteil' and the Fast Food Culture, 20 EUR. J. INT'L L. 505 (2009).

${ }^{2}$ Martin Shapiro, The European Court of Justice: Of Institutions and Democracy, 32 IsR. L. REV.. 3 (1998).
} 
The demos or the majority is free to buy or not buy the dog, but it cannot escape institutional realities. Once bought, the dog will bite. ${ }^{3}$

One part of the institutional choices faced by constitution-makers is whether to entrench constitutional courts with the restricted competence to police the division of powers or also grant them the power to adjudicate constitutional rights. In either case, constitutional courts will bite sooner or later, especially in cases of rights review, be this a constitutionally awarded or self-proclaimed judicial power.

There is extensive literature on the reasons that motivated several European countries to implement dedicated constitutional justice institutions after 1945. ${ }^{4}$ Except for Greece, all constitutional systems of post-totalitarian periods entrenched a strong constitutional court-or, like in Estonia, constitutional review was assigned to a dedicated chamber of the Supreme Court. The German Constitutional Court is the paradigm of a strong constitutional jurisdiction. Dominant narratives tend to frame the FCC as an originally intended strong court that should make the constitution resilient in reaction to the Third Reich and National-Socialism. ${ }^{5}$ But the reasons determining its empowerment do not entirely fit such a simplistic account. To be sure, the growth of the German Constitutional Court's judicial power was also a result of the changing structures of the division of powers and the commitment with an effective precept of checks and balances. The post-war growth of the state and the expansion of welfare increased the powers of the executive and legislative branches, which, in turn, legitimized the expansion of judicial power, a trend visible in other jurisdictions. Constitutional justice thus became the "ultimate crowning of the Rule of Law."

The expansion of state power, particularly at the administrative level, heightened the necessity of democratic legitimation of the newly enlarged arrays of competences and prerogatives. ${ }^{7}$ In response, throughout the decades, the FCC conceptualized three main areas to be off-limits as to what regards the primacy of EU law and the position of the CJEU as the final arbiter: (1) fundamental rights protection, (2) ultra vires review, and (3) (constitutional) identity review.

On the level of fundamental rights protection, after an initial period of animosity and indirect conflict over the right to hold the last word on constitutional interpretation, the German Court came to accept that the EU, and in particular the Court of Justice, generally ensure effective protection of fundamental rights at a level which is substantially similar to the protection afforded by the domestic constitutional order. ${ }^{8}$ In this realm, the German Court recently expanded its openness towards EU law substantially. ${ }^{9}$

Whereas rights protection has offered an avenue for judicial convergence and mutual respect, the story unfolds differently at the level of ultra vires review in connection with the democratic

\footnotetext{
${ }^{3} I d$., at $26-27$.

${ }^{4}$ See e.g. Francesco Biagi, European Constitutional Courts and Transitions to Democracy (2020); Mauro Cappelletti, Judicial Review in the Contemporary World (1971); Victor Ferreres Comella, Constitutional Courts and Democratic Values: A European Perspective (2009); Mauro Cappelletti, Repudiating Montesquieu? The Expansion and Legitimacy of "Constitutional Justice", 35 CATH. UnIV. L. REV. 1 (1985).

${ }^{5}$ For a critique, see Michaela Hailbroner, Traditions and Transformations - The Rise of German Constitutionalism (2015). On the FCC, see Anuscheh Farahat, The German Federal Constitutional Court, in Max Planck Handbooks in European Public law, vol. III: Constitutional Adjudication: Institutions 279 (Armin von Bogdandy et al. eds, 2020).

${ }^{6}$ Shapiro, supra note 2, at 2, 422.

${ }^{7}$ See Matthias Jestaedt, Democratic Legitimation of the Administrative Power - Exclusive versus Inclusive Democracy, in Debates in German Public Law 181 et seq. (Hermann Pünder et al eds., 2014).

${ }^{8}$ Bundesverfassungsgericht [BVerfG] [Federal Constitutional Court] Oct. 22, 1986, 73 EnTsChEIDUnGEN Des BundesVERFASSUNGSGERICHTS [BVERFGE] 339 [Solange II]; Bundesverfassungsgericht [BverfG] [Federal Constitutional Court] June 7, 2000, 102 Entscheidungen Des Bundesverfassungsgerichts [BVerfGE] 147 [Banana Market].

${ }^{9}$ Bundesverfassungsgericht [BVerfG] [Federal Constitutional Court], Case No. 1 BvR 276/17 (Nov. 6, 2019), http://www. bverfg.de/e/rs20191106_1bvr027617.html [hereinafter Right to be Forgotten II].
} 
principle. As we know, it is the precisely the FCC's interpretation of one of the central normative tenets of the German constitutional order-the democratic principle-in the context of the de-territorialization of power and the transfer of competences to supranational institutions that provides the stage for the recent clash with the CJEU. Reconciliation between national democracy and the transfer of powers to supranational organizations is the ultimate point of reference of the conflict between the two judicial institutions.

The underlying constitutional structure affecting Germany's participation in the EU remained essentially coherent over the years. This structure also entails the theoretical framework of conflict that has been reiterated and fine-tuned over the years. This framework has finally come to life in the recent ruling on the PSPP program but its roots date back to the Maastricht decision of $1992 .{ }^{10}$ It succinctly sets out the possibility of EU acts being declared inapplicable in Germany inasmuch as there is a breach in the division of powers between the Member States at the EU level, and the leading role of the German Constitutional Court as the ultimate guarantor of the Basic Law. The relevant national parameter is the democratic principle, a standard which had already proved decisive for the control of domestic public authority, particularly administrative decision-making power. ${ }^{11}$ According to this yardstick, any exercise of public authority must be democratically founded, which means that citizens must substantively consent to the exercise of political power in conditions of freedom and equality. This substantive reading of the democratic principle by the FCC entails limits to EU integration to protect the citizens' right to self-government and binds the allocation of authority at the EU level to stringent conditions of validity. The Bundestag must approve any further transfers of sovereign powers and, as guardian of the Basic Law, the FCC claimed the theoretical power to review the limits of EU's competences and to declare inapplicable in Germany any EU act that overrides the powers of the Federal Republic (ultra vires review).

Sixteen years after the Maastricht decision, the FCC, in the Lisbon judgment, just a few months before the Eurozone sovereign debt crisis detonated, rearticulated the democratic principle as a substantive constitutional limit to blanket dynamic treaty provisions and indeterminate transfers, as well as to the expansion of competences by sole virtue of EU institutional action. ${ }^{12}$ It reaffirmed its limited endorsement of the primacy of EU law and framed ultra vires and identity review as constitutional remedies to bridge the gap between the decision-making powers of the Union and the democratic power of citizens.

Moreover, the FCC encapsulated the concept of "budgetary sovereignty" to shield the Bundestag's autonomy regarding the "total amount of the burdens placed on citizens" as well as "essential state expenditure." 13 Between 2010 and 2014, the FCC further fleshened out the concept of "budgetary sovereignty" by expressing concerns with limiting the amount of budgetary responsibility ${ }^{14}$ and stressing the importance of keeping the democratic process open, an essential condition of fundamental legal reversibility as the core of the principle of democracy. ${ }^{15}$ Fiscal sovereignty and the protection of participation rights of the Bundestag in rescue mechanisms thus emerged as additional substantial limits imposed by the democratic principle to EU integration.

Theoretical potential for conflict between the two courts was, in the meantime, considerably reduced. In 2010, in the frame of the Honeywell case concerning age discrimination, the FCC

\footnotetext{
${ }^{10}$ Bundesverfassungsgericht [BverfG] [Federal Constitutional Court] Oct. 12, 1993, 89 EnTsCHEIDUNGEN Des BundESVERFASSUNGSGERICHTS [BVERFGE] 155 [hereinafter Maastricht].

${ }^{11}$ See Jestaedt, supra note 7 , at 185 et seq.

${ }^{12}$ Bundesverfassungsgericht [BverfG] [Federal Constitutional Court] June 30, 2009, 123 EnTsCHEIDUNGEN DES BUNDESVERFASSUNGSGERICHTS [BVERFGE] 267 [hereinafter Lisbon decision].

${ }^{13} I d$. At para. 256.

${ }^{14}$ Bundesverfassungsgericht [BverfG] [Federal Constitutional Court] Sept. 7, 2011, 129 EnTsCHEIDUNGEN DES Bundesverfassungsgerichts [BVerfGE] 124 [Greek Rescue Package decision].

${ }^{15}$ Bundesverfassungsgericht [BverfG] [Federal Constitutional Court] July 10, 2012, 132 EnTSCHEIDUNGEN DES BUNDESVERFASSUNGSGERICHTS 195, 268 [ESM Interim decision].
} 
raised the threshold for ultra vires review, ${ }^{16}$ reserving the risk of constitutional conflict between national constitutional law and EU law for manifest transgressions and structural violations of competences. The Court also committed itself to asking the CJEU for a preliminary ruling before declaring an EU act ultra vires. It further argued that the ruling of the Court of Justice is, in principle, binding for Karlsruhe. But Luxembourg's claim to exclusivity was, once again, not accepted.

Soon it would become clearer what type of "structurally significant transgressions" might fall under Karlsruhe radar. The bone of contention would be the powers of the ECB and, more generally, the constitutional architecture of the Economic and Monetary Union (EMU), and the underlying tension between democratic and economic constitutionalism.

Ironically, the conflict became apparent just as the FCC, for the first time after a long history of indirect judicial dialogue, conceded to a referral for a preliminary ruling to the CJEU on the program of Outright Monetary Transactions (hereinafter OMT). ${ }^{17}$ The OMT program was part of the "non-standard" 18 measures adopted by the ECB following Mario Draghi's famous pledge to save the Euro, "whatever it takes." At the outset, the unconventional road of monetary action raised concerns of breaching EU constitutional constraints ${ }^{19}$ and amounting to a possible structural transgression $^{20}$ of the vertical division of powers. ${ }^{21}$

In the referral, the Court emphasized, in authoritative terms, that the "drops in influence" (Einflussknicke) that lower the level of democratic legitimacy of an independent central bank are constitutionally accepted because there is a recognized scientific consensus that monetary policy should be insulated from competitive politics. However, such constitutional acceptance is subject to a narrow reading of the ECB's mandate, ${ }^{22}$ limited to price stability. ${ }^{23}$ It follows from the preceding analysis of the court's ultra vires and identity control decisions that such review had to be substantive, i.e that any competent court actually has to convince itself of the price stability orientation of the program.

The case was explosive: Although the program had not been implemented, it played a crucial role in the management of the crisis. Should a court quash it, the ECB's non-conventional approach to monetary policy in times of crisis, whose success was uncontested, would have been endangered in the future-and with it, the entire Eurozone.

\footnotetext{
${ }^{16}$ Bundesverfassungsgericht [BverfG] [Federal Constitutional Court] July 6, 2010, 126 Entscheidungen des Bundesverfassungsgerichts [BVerfGE] 286, para. 57 [Honeywell Decision].

${ }^{17}$ Bundesverfassungsgericht [BVerfG] [Federal Constitutional Court], Case No. 2 BvR 2728/13 (Jan. 14, 2014), http://www. bverfg.de/e/rs20160621_2bvr272813en.html [hereinafter OMT referral decision].

${ }^{18}$ As opposed to standard or conventional monetary policy measures, i.e., changes in the main policy rates.

${ }^{19}$ Essentially, the narrow mandate and the independence of the European System of Central Banks (Articles 127 and 130 TFUE), the prohibition of monetary financing (Article 123(1) TFEU), and the no-bailout clause (Article 125(1) TFEU).

${ }^{20}$ This threshold was also relevant to allow the procedural avenue of the Verfassungsbechwerde in the OMT referral (para. 53). On this, claiming that the German Court has developed an extremely broad access to constitutional review in EU affairs giving rise to an actio popularis as a specific instrument to review EU acts that are ultra vires, see Klaus Ferdinand Gärditz, Beyond Symbolism: Towards a Constitutional Actio Popularis in EU Affairs? A Commentary on the OMT Decision of the Federal Constitutional Court, 14 GERMAN L.J. 183 (2014).

${ }^{21}$ The programme had already been challenged before the General Court but the action was found inadmissible. A later appeal to the CJEU was also unsuccessful. See, respectively, ECJ, Case T-492/12, von Storch and Others v ECB, ECLI:EU: C:2015:300 (Apr. 29, 2015).

${ }^{22}$ For criticism, see Matthias Goldmann, Adjudicating Economics? Central Bank Independence and the Appropriate Standard of Judicial Review, 15 GERMAN L.J. 265 (2014).

${ }^{23}$ For further comments on the referral, see Jürgen Bast, Don't Act Beyond Your Powers: The Perils and Pitfalls of the German Constitutional Court's Ultra Vires Review, 15 GERMAN L.J. 167 (2014); Thomas Beukers, The Bundesverfassungsgericht Preliminary Reference on the OMT Program: "In the ECB We Do Not Trust. What About You?", 15 German L.J. 343 (2014); Mattias Kumm, Rebel Without a Good Cause: Karlsruhe Misguided Attempt to Draw the CJEU into a Game of "Chicken" and What the CJEU Might do About it, 15 GERMAN L.J. 203 (2014); Franz C. Mayer, Rebels Without a Cause? A Critical Analysis of the German Constitutional Court's OMT Reference, 15 GERMAN L.J. 111 (2014).
} 
In the CJEU's reply, the fault lines carving the conflict between the two courts were evidenced. ${ }^{24}$ Although the CJEU admitted that actions of the ECB are subject to judicial review under the rule of law principle, the broad discretion of its action justified the adoption of merely procedural standards of review. The CJEU endorsed a low level of scrutiny and refused to second-guess policy choices involving complex assessments in the frame of proportionality review. ${ }^{25}$ Crucially, the CJEU was satisfied with the ECB's statement that the OMT program was a monetary policy, adding that the relevant criteria were the declared objectives of the measure and not its effects, and clarified that the ECB's duty to state reasons was not subject to strict formalization.

The FCC $^{26}$ took issue with this standard of judicial review of ECB's acts. Such a light test was not, in the view of the German Court, an appropriate standard to enforce the principle of conferral, and accused the CJEU of failing to address the consequences of the independence of the ECB for the democratic legitimacy of its actions, a central topic in the order of referral.

At this point, it became clear that the two courts hold two very different readings of legal accountability of central banks' independence and discretion. Whereas the CJEU endorses a procedural approach to accountability that culminates in the exercise of a low review of the ECB's action, the FCC favors a full review to compensate for the reduction in democratic legitimacy.

\section{Constitutional Courts Do Bite: The PSPP Decision}

\section{Applying the Standard}

A subsequent bond-buying scheme adopted by the ECB originated a new exchange between the FCC and the CJEU that ultimately led to the direct clash between the two courts. The Public Sector Purchase Programme $(P S P P)^{27}$ was adopted as part of the ECB's quantitative easing policy and originated a massive change in the ownership of public sector bonds. ${ }^{28}$ By the end of 2017 , bonds in the order of 1.9 trillion had already been moved from the private sector into the hands of the $\mathrm{ECB}$ and the national central banks, thus increasing the fiscal exposure to interest rate risk in the euro area Member States.

Faced with a challenge on the legality of the PSPP, Karlsruhe referred another set of questions to the CJEU. ${ }^{29}$ Although the general tone of this second referral appeared to be less authoritative than the OMT reference, there were no substantial changes to the overall assessment of the relevant standards. ${ }^{30}$

\footnotetext{
${ }^{24}$ ECJ, Case C-62/14, Peter Gauweiler and Others v. Deutscher Bundestag, ECLI:EU:C:2015:400 (June 16, 2015), http:// curia.europa.eu/juris/liste.jsf?num=C-62/14. For a comment, see Alicia Hinarejos, Gauweiler and the Outright Monetary Transactions Programme: The Mandate of the European Central Bank and the Changing Nature of Economic and Monetary Union: European Court of Justice, Judgment of 16 June 2015, Case C-62/14 Gauweiler and others v Deutscher Bundestag, 11 Eur. Const. L. Rev. 563 (2015).

${ }^{25}$ See Mark Dawson, Adina Maricut-Akbik, \& Ana Bobić, Reconciling Independence and Accountability at the European Central Bank: The False Promise of Proceduralism, 25 Eur. L.J. 75 88-91 (2019); Hinarejos, supra note 24. Light judicial review of central bank's decision is claimed by a diverse literature. See, e.g., Goldmann, supra note 23.

${ }^{26}$ Bundesverfassungsgericht [BVerfG] [Federal Constitutional Court] June 21, 2016, 142 ENTSCHEIDUNGEN DES BUNDESVERFASSUNGSGERICHTS [BVERFGE] 123 [hereinafter OMT decision].

${ }^{27}$ Decision (EU) 2015/774 of the European Central Bank of 4 March 2015 on a secondary markets public sector asset purchase programme, as amended by Decision (EU) 2017/100 of the European Central Bank of 11 January 2017.

${ }^{28}$ See Harmen Lehment, Fiscal Implications of the ECB's Public Sector Purchase Programme, Supp. 2 REvUE DE L'OFCE 89 (2019).

${ }^{29}$ Bundesverfassungsgericht [BVerfG] [Federal Constitutional Court] July 18, 2017, 146 ENTSCHEIDUNGEN DES BUNDESVERFASSUNGSGERICHTS [BVERFGE] 216 [hereinafter, PSPP referral decision].

${ }^{30}$ For comments see Alicia Hinarejos, On-Going Judicial Dialogue and the Powers of the European Central Bank: Weiss, 63 Revista de Derecho Comunitario Europeo 651 (2019); Andrej Lang, National Courts Ultra Vires review of the ECB's Policy of Quantitative Easing: An Analysis of the German Constitutional Court's Preliminary Reference Order in the PSPP case, 55 CoмM. Мкт. L. Rev. 923 (2018).
} 
The Court specifically stressed that the absence of a reasoning underlying the weighing of the economic policy effects against the program's monetary effects prevented judicial review of its proportionality.

The CJEU's reply ${ }^{31}$ followed its approach in Gauweiler and limited itself to a "light-touch review" 32 that failed to meaningfully address two central topics of the FCC's referral: The concerns over the proper scrutiny of a politically-insulated institution such as the ECB, and the effective weighing of the PSPP's distributive effects against the monetary gains. ${ }^{33}$ While the FCC urged the CJEU to hold the ECB's policy to substantial account, the latter insisted on a deferential control. It did not examine the effects of the PSPP, but limited to check its form and stated objective, thus precluding the possibility of substantially reviewing the contested measures.

\section{The FCC's Defiance: The PSPP Decision}

It is at this juncture that we find the direct clash between the two courts. In its May 5, 2020 ruling, the FCC openly refused obedience to the CJEU for the first time. ${ }^{34}$

The center of dissent revolves around the intensity of judicial scrutiny of the ECB's actions in the area of monetary policy. By refusing to take the cue expressed in the referral that the validity of the measure in light of the conferral of competences should convey a balanced analysis of the declared monetary objective with the economic and fiscal effects, the CJEU lent itself to the accusation of employing a methodologically flawed analysis that might ultimately render untenable the proportionality review in the concept construed by the FCC. Whereas the German Court claims that the indirect effects of the program must be balanced against the monetary gains, the Court of Justice limits its review to certain procedural safeguards, explicitly refusing the substantive weighing demanded by the FCC. The methodological dissent reached, according to the German judges, the qualified threshold necessary to trigger the ultra vires censorship. This is indicative that the underlying disagreement is not reduced to a simple dispute over different interpretative techniques, but a structural divergence on the nature of proportionality review as a relevant yardstick to enforce the division of powers between the EU and its Member States. In the words of the German judges, the CJEU's standard of control would not "prevent such purchases even if they constituted an abuse of law." 35 In the eyes of the German judges, the CJEU's procedural standard of control prevents an effective scrutiny of the ECB's actions and fails to provide a credible enforcement of the division of competences between monetary policy and the Member States' powers over economic and fiscal choices.

The conflict between the two institutions reached its peak when the FCC considered the CJEU's decision as an ultra vires act for its lack of legal competency and a manifest breach of the mandate conferred by Article 19(1) TEU.

The FCC finds that the PSPP breaches Articles 5(1) second sentence and 5(4) TEU, and, consequently, the monetary policy mandate enshrined in Article 127 TFEU because there is a lack of statement of reasons by the ECB clarifying that a balance between the objective of the measure and its effects must be expressly articulated. ${ }^{36}$ To the FCC, judicial review of the ECB's actions claims more than the procedural and deferential scrutiny applied by the CJEU. The German Court would

\footnotetext{
${ }^{31}$ ECJ, Case C-493/17, Heinrich Weiss and Others, ECLI:EU:C:2018:1000 (Dec. 11, 2018), paras. 46-52, http://curia.europa. eu/juris/liste.jsf?num $=\mathrm{C}-493 / 17$ [hereinafter Weiss].

${ }^{32}$ See Hinarejos, supra note 30 , at 663.

${ }^{33}$ For a persuasive critique of the "idea of a virtuous circle between independence and accountability of central banks" see Dawson, Maricut-Akbik \& Bobić, supra note 25.

${ }^{34}$ Bundesverfassungsgericht [BVerfG] [Federal Constitutional Court], Case No. 2 BvR 859/15, (May 5, 2020), https://www. bundesverfassungsgericht.de/SharedDocs/Entscheidungen/EN/2020/05/rs20200505_2bvr085915en.html [hereinafter PSPP decision]

${ }^{35} I d$., at para. 137.

${ }^{36} I d$., at para. $176-177$.
} 
not refrain from a substantive review of the PSPP in light of the concerns raised by the ECB's independence to the democratic principle, and the program's major side-effects on fiscal policy.

\section{The Lack of Statement of Reasons: A Substantive Review and a Weak Remedy}

At this point in the reasoning, the German court had two options. The first would be to refer back the case to the CJEU to complete its proportionality review in light of an articulated statement of reasons - that the Court would have to gather near the ECB. The second was rejecting the authority of the CJEU in this specific question and addressing directly the German constitutional organs. Although the first option might be argued as not only advisable but even mandatory considering the doctrine of mutual cooperation detailed at length by the German court itself, it might also have proved risky to the integrity of the EU law should the response not be satisfactory for the FCC's standards.

The noteworthy aspect of the PSPP ruling lies in its intrinsically weak remedy despite the strong, substantial claims on the conditions that may render the PSPP acceptable under EU and national constitutional law. The criticism directed at the CJEU reflects the fact that by failing to demand such justifications from the ECB, the Luxembourg Court prevents the effective judicial review of the measure. The central point of disagreement between the two courts thus lies in a question related not to the substantive content of the decision but to a substantial disagreement over accountability of the ECB's unconventional measures and the monetarization of fiscal objectives. In fact, it is unclear, at this moment, whether in a future occasion the Court will subject effective administrative justifications to a strict review, thereby opening the possibility of replacing primarily technical assessments with its own.

As the FCC finds itself incapable of effectively reviewing the proportionality of the measure, its scrutiny culminates in a deferred and conditional declaration of unconstitutionality. The anticipated illegality can be averted during a transitional period of three months if two conditions are met: First, that the ECB provides a proportionality assessment; and, second, that such assessment is validated by the Federal Government and the Bundestag. The FCC thus deflects the CJEU's authority to deliver the last word on the constitutionality of a controversial monetary policy to defer the final assessment to the political organs.

The Court's choice deserves some remarks. On the one hand, the Court identified the institutions which are responsible for executing the judgment, in conformity with the powers enshrined in Article 35 BVerfGG, first sentence. It also provided some guidelines as to how the decision can be implemented, clarifying that, in ensuring that the ECB fulfills the omission in its reasoning, the Federal Government and the Bundestag must clearly communicate their legal view. But this is only a possibility, as the Court further adds that "other steps" can be followed to ensure compliance with the ruling. It is noteworthy that the FCC refrained from clarifying by what means should the execution take place, a possibility expressly envisaged in Article 35 BVerfGG, second sentence. In fact, the Court could have provided more detailed conditions regarding the method of enforcement, thus binding its interlocutors to the adoption of specific implementation schemes. Through such a writ, the Court would have been able to decide not only which institutions were responsible for executing the decision but also how the execution should proceed. ${ }^{37}$ By avoiding the use of this power, the Court restrained from precluding the Bundestag and the Federal Government's margin of assessment in the definition of the means to give satisfaction to the judicial ruling, thus deferring that action to the political branches.

This procedural option has important consequences: Only if there was no further justification of the proportionality of the program from the ECB could the complainants initiate a successful enforcement order of the decision under Article 35 BVerfGG. ${ }^{38}$ More importantly, by deferring to

\footnotetext{
${ }^{37}$ On the orders for implementation of the Bundersverfassungsgericht, see Farahat, supra note 5, at 331.

${ }^{38}$ Only if the institutions addressed by the duty to implement the judicial decision "do not act at all or act only in a way that is so obviously behind the requirements resulting from the decision on the merits that it is tantamount to inaction." See
} 
the Federal Government and the Bundestag the power to scrutinize the justification of the ECB, the FCC devolves the conflict to its primary field: The political level. The last word on unconventional monetary policy should not be delivered by a court. It is foremost a political problem that conveys a reasonable amount of economic disagreement and uncertainty and where the judicial contribution in the enforcement of constitutional standards should be limited to instigating debate and deliberation without foreclosing or pre-empting politics. ${ }^{39}$ Endorsing a substantive standard of review for contested monetary policies does not risk legitimacy charges if the legislature retains the final word about constitutional compliance.

In this decision, the FCC employed a remedy that seems to combine the features of deferred and conditional decisions of unconstitutionality. The unconstitutionality is not only suspended, it is also provisional: If justification is provided by the ECB in the three-month period and considered sufficient to alleviate the constitutional concerns outlined by the Court, then the effects on the legality of the PSPP program are simply not produced. Moreover, ascertaining the sufficiency of the future reasoning supplemented by the ECB is a political judgment incumbent upon the Federal Government and the Bundestag, as long as there is some reasoning put forward to these constitutional organs so that the standard for an order of execution is not triggered ${ }^{40}$. It can therefore be constructed as a weak remedy that defers a broad margin of execution and assessment to the political process, reserving further eventual judicial intervention only to cases of full absence of compliance with the ruling. ${ }^{41}$ This option conveys the understanding of the Court's institutional limitations. Ultimately, the capacity to assert if the ECB's statement of reasons proves convincing for the respect of national competences, is a matter for the political branches to evaluate. The Court's role is reserved to ensuring that a substantial review of the ECB's policies is permissible, on the one hand, and that the democratic institutions will not shy away from their duties to enforce the constitutional limits to integration, on the other.

\section{Constitutional Courts Against Competence Creep}

Much of the criticism against the FCC's substantial review of monetary policy measures takes the view that social controversies involving difficult and complex assessments recommend cautious judicial approaches. In fact, possible EU violations of national sovereignty convey not only legal but also political judgments for which other constitutional organs are competent. However, that should not prompt us into a swift endorsement of judicial restraint. Indeed, judicial abdication may contribute to reinforcing political dysfunctionalities in cases where the political branches have incentives to ignore difficult constitutional questions-what Mark Graber calls the "legislative deference to the judiciary." 42 The development of the EMU during and after the financial crisis may be one of those cases.

From 2011 onwards, the ESCB gained unprecedented power over the Eurozone and the Member States. Despite its founding technocratic and apolitical nature, the Eurocrisis forced the ECB to undertake several policy actions given the absence of strong political authority in

\footnotetext{
Bundesverfassungsgericht [BVerfG] [Federal Constitutional Court] June 6, 2010, 142 ENTSCHEIDUNGEN DES BuNDESVERFASSUNGSGERICHTS [BVERFGE] 116.

${ }^{39}$ See Robert Post, Theorizing Disagreement: Reconceiving the Relationship Between Law and Politics, 98 CAL. L. REV. 1319, 1346-1347 (2010).

${ }^{40}$ See 142 BVERFGE 116.

${ }^{41}$ I rely here on the distinction developed by Mark Tushnet between strong-form and weak-form mechanisms of judicial review that focuses on the power of courts to restrict the actions of the political branches. Strong-form mechanisms reserve the final word on constitutional compliance to the courts, whereas weak-forms of judicial review defer the final say to the political institutions. See Mark Tushnet, Weak Courts, Strong Rights. Judicial Review and Social Welfare Rights in Comparative Constitutional Law (2008).

${ }^{42}$ Mark Graber, The Nonmajoritarian Difficulty: Legislative Deference to the Judiciary, 7 STUD. IN AMER. POL. DEV. 35 (1993).
} 
the EMU. This extended power is in part a result of a new expansionary reading of its mandate on monetary policy. Concerns with a possible overreach were voiced from the moment Draghi announced the "unconventional" turn. As the ECB's powers grew, so did the fiscal effects of monetary policy and unsettlement over its lack of democratic legitimacy. ${ }^{43}$

The growing uneasiness of the Second Senate is explained by this particular mode of crisis management based on growing technocratization and depoliticization of the EMU to the detriment of national democratic legitimation. ${ }^{44}$ It is of no coincidence that the frictions were clearly voiced in 2014, when the immense power concentrated in the hands of the ECB was finally visible.

The PSPP decision forces a political clarification and drags its institutional counterparts-the German constitutional organs with competence to implement the Integrationsprogramm-to confront the underlying nature of the EMU. The FCC's ruling opens an opportunity to politicize integration by stealth. In fact, the decision provides an avenue for the judicial enforcement of structural provisions of national and EU constitutional law concerning the allocation of decision-making responsibility.

The democratic principle claims that those who are affected by a decision must be given an opportunity to participate in its making. Depoliticization of decision-making at the European level leads to increased concerns over democratic deficits. Moreover, as noted above, accountability of the "independent branch" 45 may not be sufficient to fill in the accountability gaps. Against this background, national constitutional courts are in a privileged institutional position to serve as effective counterchecks to the "democracy-diminishing mechanisms at work in the EU."46

Albeit the sustained fear that the FCC's recent decision might be employed by persons responsible for Europe's autocratic tendencies to claim independence from EU law constraints and thereby to reject the CJEU's authority, its inspirational drive may surface elsewhere, near other sister courts which have in the recent past also confronted consequences of crisis-induced developments in the EMU. ${ }^{47}$ As we know, constitutional courts of borrower countries have suffered the stress of some of those crisis-induced developments in their domestic jurisdictions. ${ }^{48}$

It is particularly important to recall the trajectory of the Portuguese Constitutional Court (PCC) during the Eurocrisis. ${ }^{49}$ Faced with challenges to austerity policies adopted in the context of a financial assistance program, the Court invalidated several austerity measures aimed at redressing the fiscal balance. To that end, it developed a strategy of "nationalization of the crisis," 50 insulating the measures from the reach of EU law despite the EU genealogy of the Portuguese

\footnotetext{
${ }^{43}$ See A. L. Högenauer \& D. Howarth, Unconventional Monetary Policies and the European Central Bank's Problematic Democratic Legitimacy, 17 J. PUB. L. 1 (2016).

${ }^{44}$ See KaArlo Tuori \& Klaus Tuori, The Eurozone Crisis: A Constitutional Analysis 209 et seq. (2014).

${ }^{45}$ See Antoine Vauchez, Democratizing Europe 50 et seq. (2016). See also Frank Vibert, The Rise of the Unelected: DEMOCRACY AND THE NEW SEPARATION OF POWERS (2007).

${ }^{46}$ See Dieter Grimm, The Role of National Constitutional Courts in European Democracy, in THE CONSTITUTION OF THE European Democracy 181, 205 (2016). See also Alicia Hinarejos The Euro Area Crisis in Constitutional Perspective 144 et seq. (2015) (claiming the special position of national constitutional courts to enforce social rights in situations of financial instability); Jan Komárek, National Constitutional Courts in the European Constitutional Democracy, 12 INT'L J. ConsT. LAW 525 (2014); VAUCHEZ, supra note 45, at 46-47.

${ }^{47}$ On these developments, see Menelaos Markakis, AcCountability in the ECONOMIC AND Monetary UniOn 18 et seq. (2020).

${ }^{48}$ These are also strong constitutional courts implemented after constitutional transitions from totalitarian regimes, that "often follow the intellectual leadership of the German Constitutional Court." See Anneli Albi \& Samo Bardutzky, Revisiting the Role and Future of National Constitutions in European and Global Governance: Introduction to the Research Project, in National Constitutions in European and Global Governance: Democracy, Rights, The Rule of LaW 17 (2019).

${ }^{49}$ Miguel Poiares Maduro has already commented that the Bundesverfassungsgericht's "parochial" approach resonates the PCC's strategy during the Eurocrisis. See Miguel Poiares Maduro, Some Preliminary Remarks on the PSPP Decision of the German Constitutional Court, VerfBlog (May 6, 2020), https://verfassungsblog.de/some-preliminary-remarks-on-thepspp-decision-of-the-german-constitutional-court/.

${ }^{50}$ See Teresa Violante \& Patrícia André, The Constitutional Performance of Austerity, in Constitutions IN TIMES OF FinANCIAL CRisis 254 (Tom Ginsburg et al eds. 2019). Miguel Poiares Maduro, António Frada \& Leonardo Pierdominici
} 
bailout documents. ${ }^{51}$ It has been argued that in doing so it not only avoided open confrontation with the European judicial system but also shielded national sovereignty and the democratic constitutional order in a context where the legislature was put against intense pressure. ${ }^{52}$ According to this line of interpretation, the Eurocrisis promoted a shift in the separation of powers, lending the Constitutional Court the primary role as guardian of national sovereignty $y^{53}$ in a context where the parliament had no alternative but to submit to the Troika's demands. ${ }^{54}$

Whereas the PCC's main concern was the protection of the national welfare state and the individual rights of workers and pensioners, the FCC's predominant reading caters to ordoliberal and conventional understandings of monetary policy which were precisely at the basis of intra-Eurozone large capital flows that emerged in the decade before the crisis. In both cases, however, national constitutional courts provided avenues for contesting processes that divert redistributive policies from democratic fora. In this sense, the role of national constitutional courts in the European process is reconfigured not as the ultimate guardians of human rights, but as agents of a complex institutional structure of "communicative arrangements which generate decisions that remain open to further revision, and are subject to communicativelygenerated legitimacy." 55

National constitutional courts are in a special position to react to political malfunctions at the EU level. They have provided adequate channels to the articulation of contestation against EU Law that have thus far failed to be meaningfully addressed at other institutional levels. ${ }^{56}$ On the one hand, the CJEU is generally recognized as a biased enforcer of the separation of powers, both in its vertical and horizontal dimensions. It usually intervenes to legitimate the vertical expansion of EU competences to the detriment of Member States through the interpretation of the Treaties. ${ }^{57}$ Moreover, it is commonly recognized that the CJEU fails as a credible arbitrator of the horizontal separation of powers in the EU. Furthermore, the judicial doors at EU level will hardly open to individuals willing to invalidate an EU law measure, ${ }^{58}$ and hard cases have prompted the Court in the past to decline jurisdiction too easily on preliminary references concerning financial assistance

have qualified the PCC's strategy as “autarchic". See Miguel Poiares Maduro, António Frada, \& Leonardo Pierdominici, $A$ Crisis Between Crises: Placing the Portuguese Constitutional Jurisprudence of Crisis in Context, 4 E-PúbliCA 5 (2017).

${ }^{51}$ See Claire Kilpatrick, Are the Bailouts Immune to EU Social Challenge Because They Are Not EU Law?, 10 EUR. CONST. L. Rev. 393 (2014); Francisco Pereira Coutinho, Austerity on the loose in Portugal: European judicial restraint in times of crisis, 8 Perspectives on Federalism 105 (2016).

${ }^{52}$ See Carlos Blanco de Morais, Curso de Direito Constitucional: Teoria da Constituição em Tempo de Crise do Estado Social, Tomo II, vol. 2, 774 (2014); Roberto Cisotta \& Daniele Gallo, The Portuguese Constitutional Court Case Law on Austerity Measures: A Reappraisal, in Social Rights in Times of Crisis in the Eurozone: The Role of Fundamental Rights' Challenges 92-93 (Claire Kilpatrick \& Bruno De Witte eds., 2014); Jorge Reis Novais, Em Defesa do Tribunal Constitucional: Resposta aos Críticos 190 (2014); Cristina Fasone, Constitutional Courts Facing the Euro Crisis. Italy, Portugal and Spain in a Comparative Perspective, EUI WORKING PAPER MWP 2014/25, 51; Miguel Nogueira de Brito, Putting Social Rights in Brackets? The Portuguese Experience with Welfare Rights Challenges in Times of Crisis, 1-2 EuR. J. Soc. L. 100 (2014); Miguel Nogueira, La Jurisprudencia de la "Crisis" del Tribunal Constitucional Portugués, 38 Teoría y Realidad Constitucional 599, 599-602 (2016); Miguel Nogueira, A Comment on Miguel Poiares Maduro's “Crisis between Crises”: The Portuguese Constitutional Court's Jurisprudence of Crisis between Autarchy and Sovereignty, 4 E-PúBLICA 43 (2017).

${ }^{53}$ The Portuguese Constitution contains a clause governing the relationship between EU law and domestic law. According to Article 8(4), primacy and direct effect are recognized "with respect for the fundamental principles of the democratic state based on the rule of law."

${ }^{54}$ The protection of national parliaments through domestic judicial avenues raises, however, the problem of uneven political participation given the different national procedural structures. See Cristina Fasone \& Nicola Lupo, Constitutional Review and the Powers of National Parliaments in EU Affairs, in National Parliaments After the Lisbon Treaty AND the EURo CRISIS 60 (Davor Jančić ed., 2017).

${ }^{55}$ Jan Komárek, supra note 46, at 542.

${ }^{56}$ See generally ANUSCheh Farahat, Transnationale Solidaritätskonflikte - Eine Vergleichende ANAlyse VERFASSUNGSGERICHTLICHER KONFLIKTBEARBEITUNG DER EUROKRISE (2020) (unpublished manuscript) (on file with author).

${ }^{57}$ See Cristina Fasone \& Nicola Lupo, supra note 54, at 61-62.

${ }^{58}$ See Markakis, supra note 47 , at 204 et seq. 
conditionality. ${ }^{59}$ On the other hand, the plethora of accountability mechanisms of a political, legal, and administrative nature has not produced a substantial oversight of the ECB. ${ }^{60}$

Judicial review of EU acts in the context of the EMU by national constitutional courts opens up the process of political deliberation and renders the democratic principle meaningful in a context where the independence of central banks rise as an equally binding constitutional value. Their argumentation provides counterchecks to hegemonic narratives that are usually dominant in situations of crisis where an aura of exceptionalism prevents the consideration of alternative narratives and political contestation is precluded by the inevitability discourse. ${ }^{61}$ Their ultimate merit lies in the fact that they can meaningfully address the process of depoliticization of European integration. ${ }^{62}$

\section{E. Conclusion}

In hindsight, the evolving indirect and direct dialogue between the FCC and the CJEU is the story of a clash foretold. Whereas the German Court's First Senate appears to endorse a deeper commitment to cooperation with the CJEU and openness to the EU legal order on fundamental rights' review, ${ }^{63}$ the Second Senate toughened its interrogations on the encroachment of the right to democratic self-government by crisis-induced developments in EU processes. The main concern for the Second Senate is now the control of the ECB's monetary action insofar as it affects internal redistributive processes. By outlining the redistributional effects of the ECB's monetary policy, the Court pledges for stronger democratic control which, at the current stage, can only be achieved indirectly.

Instead of its previous cautious approach, the Court has delivered a provisional clearance of the PSPP program, subject to a specific conditionality complementing a substantive review of the CJEU's arguments with a weak means of enforcement, thereby deferring the constitutional implementation almost entirely to the political organs.

Importantly, the FCC showed that it is not afraid to bite if upholding the constitutional essentials so requires even in the context of monetary policy and the integrity of the Eurozone. It delivered a serious warning as to the unsustainability of anchoring solidarity and redistribution processes on monetary means.

Concerns as to the legitimacy of national constitutional courts to review monetary policy and economic questions of a complex technical nature are valid. They are, however, reduced by the weak remedy adopted by the FCC in the ruling, conveyed in a deferred and provisional declaration of unconstitutionality. For the time being, the bite was soft.

\footnotetext{
${ }^{59}$ See ECJ, C-128/12, Sindicato dos Bancários do Norte and Other v. BPN, ECLI:EU:C:2013:149 (Mar. 7, 2013), http://curia. europa.eu/juris/liste.jsf?num=C-128/12; ECJ, C-264/12 Sindicato Nacional dos Profissionais de Seguros e Afins v. Fidelidade Mundial, ECLI:EU:C:2014:2036 (June 26, 2014), http://curia.europa.eu/juris/liste.jsf?num=C-264/12; ECJ, C-665/13 Sindicato Nacional dos Profissionais de Seguros e Afins v. Via Directa, ECLI:EU:C:2014:2327 (Oct. 21, 2014), http://curia.europa.eu/ juris/liste.jsf?num=C-665/13.

${ }^{60}$ See Dawson, Maricut-Akbik, \& Bobić, supra note 25, at 85-88; Markakis, supra note 47, at 106 et seq.

${ }^{61}$ See Anuscheh Farahat \& Teresa Violante, Combatting TINA-Rhetoric through Judicial Review: Dealing with Pay Cuts in Times of Financial Consolidation, VERFBLOG, (Dec. 11, 2018), https://verfassungsblog.de/combatting-tina-rhetoric-throughjudicial-review-dealing-with-pay-cuts-in-times-of-financial-consolidation/.

${ }^{62}$ Arguing against increasing judicial involvement in fiscal affairs, see FEDERICO FABbrini, ECONOMIC GOVERNANCE IN Europe. Comparative Paradoxes and Constitutional Challenges 108 et seq. (2016).

${ }^{63}$ Right to be Forgotten II, at para. 42. For a comment, see Matej Avbelj, The Federal Constitutional Court Rules for a Bright Future of Constitutional Pluralism, 21 GERMAN L.J. 27 (2020).
} 
Through its incremental case law, the FCC has outlined a doctrinal toolbox to structure the ECB's discretionary powers and thus substantially enable judicial review of its actions. This is not a small achievement. What remains to be seen is whether other sister courts will follow Karlsruhe's lead in openly defying the democratic insufficiencies of EU integration. 